\title{
NARKOBA DAN PENCEGAHANNYA
}

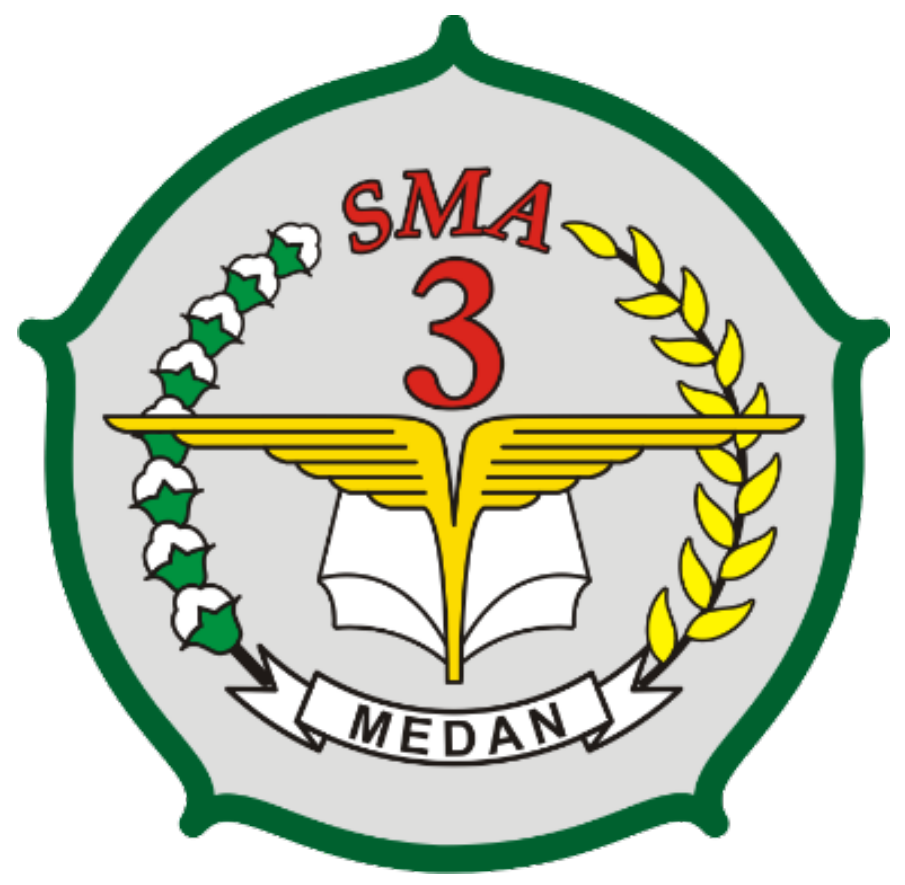

\section{DISUSUN OLEH :}

ARYA DANU HARTONO

X MIA 4

T.A 2019/2020 


\section{KATA PENGANTAR}

Puji syukur kehadirat Allah SWT karena dengan rahmat dan hidayahNya, penulis dapat menyelesaikan makalah ini dengan baik dan lancar. Shalawat dan salam penulis sampaikan kepada junjungan kami Nabi Muhammad SAW yang telah memberi petunjuk sehingga berada di jalan yang benar. Bahan ajaran yang penulis susun ini mempunyai tujuan menyediakan materi pembahasan penyalahgunaan narkoba.

Makalah ini disusun agar semua dapat mengetahui apa saja bahaya dan dampak buruk dari narkoba yang kami sajikan berdasarkan pengamatan dari berbagai sumber. Makalah ini kami susun dengan berbagai rintangan. Baik itu yang datang dari diri kami maupun yang datang dari luar. Namun dengan penuh kesabaran dan terutama pertolongan dari Tuhan akhirnya makalah ini dapat terselesaikan.

Walaupun penulis telah menyusun materi ini kemungkinan terdapat kelebihan maupun kekurangan. Sehubungan dengan hal tersebut, penulis mengharapkan masukan dari pihak pengajar dan pihak peserta untuk perbaikan.

Penyusun

Arya Danu Hartono

X MIA 4 
DAFTAR ISI

\section{KATA PENGANTAR}

\section{DAFTAR ISI}

\section{ABSTRAK}

\section{BAB I PENDAHULUAN}
A. Latar Belakang
B. Identifikasi Masalah
C. Rumusan Masalah
D. Tujuan Masalah
E. Manfaat Penulisan

\section{BAB II PEMBAHASAN}

\section{KAJIAN TEORI}
A. Pengertian Narkoba
B. Jenis dan Macam - Macam Narkoba
C. Penyalahgunaan Narkotika/Psikotropika di Kalangan Remaja
D. Dampak Penyalahgunaan Narkoba
E. Tanda-Tanda Penyalahgunaan Narkoba
F. Faktor Penyebab Penyalahgunaan Narkotika
G. Pengobatan Dan Pencegahan

\section{HAKIKAT TEORI}

\section{BAB III PENUTUP}
A. Kesimpulan
B. Saran 


\section{BAB I}

\section{PENDAHULUAN}

\section{A. Latar Belakang}

Salah satu persoalan besar yang tengah dihadapi bangsa Indonesia, dan juga bangsabangsa lainnya di dunia saat ini adalah seputar maraknya penyalahgunaan narkotika dan obatobatan berbahaya (narkoba), yang semakin hari semakin mengkhawatirkan.

Saat ini, jutaan orang telah terjerumus ke dalam 'lembah hitam' narkoba. dan ribuan nyawa telah melayang karena jeratan 'lingkaran setan' bernama narkoba. Telah banyak keluarga yang hancur karenanya dan tidak sedikit pula generasi muda yang kehilangan masa depan karena perangkap 'makhluk' yang disebut narkoba ini.

Masalah penyalahgunaan narkoba di Indonesia merupakan masalah serius yang harus dicarikan jalan penyelesaiannya dengan segera. Banyak kasus yang menunjukkan betapa akibat dari masalah tersebut diatas telah menyebabkan banyak kerugian, baik materi maupun non materi. Banyak kejadian, seperti perceraian atau kesulitan lain bahkan kematian yang disebabkan oleh ketergantungan terhadap narkotika dan obat-obat terlarang.Hal inilah yang mendorong kami untuk mengungkit masalah sebagai bahan diskusi.

Narkoba adalah singkatan dari narkotika dan obat/bahan berbahaya. Selain "narkoba", istilah lain yang diperkenalkan khususnya oleh Kementerian Kesehatan Republik Indonesia adalah Napza yang merupakan singkatan dari narkotika, psikotropika, dan zat adiktif.

Semua istilah ini, baik "narkoba" ataupun "napza", mengacu pada kelompok senyawa yang umumnya memiliki risiko kecanduan bagi penggunanya. Menurut pakar kesehatan, narkoba sebenarnya adalah senyawa-senyawa psikotropika yang biasa dipakai untuk membius pasien saat hendak dioperasi atau obat-obatan untuk penyakit tertentu. Namun kini persepsi itu disalahartikan akibat pemakaian di luar peruntukan dan dosis yang semestinya.

Narkotika adalah zat atau obat yang berasal dari tanaman atau bukan tanaman, baik sintetis maupun semi sintetis yang dapat menyebabkan penurunan atau perubahan kesadaran, hilangnya rasa nyeri dan dapat menimbulkan ketergantungan (Undang-Undang No. 35 tahun 
2009). Narkotika digolongkan menjadi tiga golongan sebagaimana tertuang dalam lampiran 1 undang-undang tersebut. Yang termasuk jenis narkotika adalah:

- Tanaman papaver, opium mentah, opium masak (candu, jicing, jicingko), opium obat, morfina, kokaina, ekgonina, tanaman ganja, dan damar ganja.

- Garam-garam dan turunan-turunan dari morfina dan kokaina, serta campurancampuran dan sediaan-sediaan yang mengandung bahan tersebut di atas.

Psikotropika adalah zat atau obat, baik alamiah maupun sintetis bukan narkotika, yang berkhasiat psikoaktif melalui pengaruh selektif pada susunan saraf pusat yang menyebabkan perubahan pada aktivitas mental dan perilaku (Undang-Undang No. 5/1997).

Terdapat empat golongan psikotropika menurut undang-undang tersebut, namun setelah diundangkannya UU No. 35 tahun 2009 tentang narkotika, maka psikotropika golongan I dan II dimasukkan ke dalam golongan narkotika. Dengan demikian saat ini apabila bicara masalah psikotropika hanya menyangkut psikotropika golongan III dan IV sesuai UndangUndang No. 5/1997. Zat yang termasuk psikotropika antara lain: Sedatin (Pil BK), Rohypnol, Magadon, Valium, Mandrax, Amfetamine, Fensiklidin, Metakualon, Metifenidat, Fenobarbital, Flunitrazepam, Ekstasi, Shabu-shabu, LSD (Lycergic Syntetic Diethylamide) dan sebagainya.

\section{B. Identifikasi Masalah}

Identifikasi Masalah berdasarkan uraian di atas terdapat masalah yang di Identifikasi, antara lain:

1. Masih kurangnya pemahaman siswa mengenai Narkoba

2. Masih kurangnya pemahaman siswa mengenai macam-macam jenis Narkoba

3. Masih kurangnya pemahaman siswa pada cara pencegahan dan pengobatan Narkoba

\section{Rumusan Masalah}

Permasalahan yang dapat dirumuskan sebagai berikut:

1. Apa pengertian dan jenis-jenis narkoba?

2. Bagaimanakah penyalahgunaan narkotika/psikotropika?

3. Bagaimanakah faktor/sebab dan akibat penggunaan penyalahgunaan narkotika?

4. Bagaimanakah cara pengobatan dan pencegahanannya? 


\section{Tujuan Masalah}

Sesuai dengan masalah penelitian, maka tujuan dalam penelitian ini adalah :

1. mengetahui narkoba yang sering disalahgunakan

2. mengetahui pengaruh dari narkoba

3. mengetahui alasan orang kecanduan narkoba

4. mengetahui solusi dan upaya penyembuhan narkoba

\section{F. Manfaat penulisan}

Untuk memberikan informasi tentang narkoba dan bahayanya agar kita tidak terjerumus didlamnya serta kita bisa menjadi penerus bangsa yang bersih dari narkoba. 


\section{BAB II \\ PEMBAHASAN}

KAJIAN TEORI

\section{A. Pengertian Narkoba}

Narkoba (singkatan dari Narkotika, Psikotropika dan Bahan Adiktif berbahaya lainnya) adalah bahan / zat yang jika dimasukan dalam tubuh manusia, baik secara oral / diminum, dihirup, maupun disuntikan, dapat mengubah pikiran, suasana hati atau perasaan, dan perilaku seseorang. Narkoba dapat menimbulkan ketergantungan (adiksi) fisik dan psikologis.

Narkotika adalah zat atau obat yang berasal dari tanaman atau bukan tanaman, baik sintetis maupun semi sintetis yang dapat menyebabkan penurunan atau perubahan kesadaran, hilangnya rasa nyeri dan dapat menimbulkan ketergantungan (Undang-Undang No. 22 tahun 1997).

\section{B. Jenis - Jenis Narkoba}

- Berdasarkan efeknya, narkoba bisa dibedakan menjadi tiga:

1. Depresan, yaitu menekan sistem sistem syaraf pusat dan mengurangi aktifitas fungsional tubuh sehingga pemakai merasa tenang, bahkan bisa membuat pemakai tidur dan tak sadarkan diri. Bila kelebihan dosis bisa mengakibatkan kematian. Jenis narkoba depresan antara lain opioda, dan berbagai turunannya seperti morphin dan heroin. Contoh yang populer sekarang adalah Putaw.

2. Stimulan, merangsang fungsi tubuh dan meningkatkan kegairahan serta kesadaran. Jenis stimulan: Kafein, Kokain, Amphetamin. Contoh yang sekarang sering dipakai adalah Shabushabu dan Ekstasi.

3. Halusinogen, efek utamanya adalah mengubah daya persepsi atau mengakibatkan halusinasi. Halusinogen kebanyakan berasal dari tanaman seperti mescaline dari kaktus dan psilocybin dari jamur-jamuran. Selain itu ada jugayang diramu di laboratorium seperti LSD. Yang paling banyak dipakai adalah marijuana atau ganja.

- Berdasarkan jenisnya,narkoba di bedakan menjadi:

1. Opiada, Terdapat 3 golongan besar:

a. Opioda alamiah (Opiat): Morfin,Opium,Codein. 
b. Opioda semisintetik: Heroin/Putauw,Hidromorfin.

c. Opioda sintetik: Metadon.

\section{Kokain}

Kokain berupa Kristal putih,rasanya sedikit pahit dan lebih mudah larut. Nama jalanan: koka,coke,happy dust,chalie,srepet,snow/salju. Cara pemakaiannya: membagi setumpuk kokain menjadi beberapa bagian berbaris lurus di atas permukaan kaca atau alas permukaannya datar kemudian dihirup dengan menggunakan penyedot sepertisedotan atau dengan cara dibakar bersama dengan tembakau.penggunaan dengan cara dihirup akan beresiko kering dan luka pada sekitar lubang hidung bagian dalam. Efek pemakaian kokain: pemakain akan merasa segar,kehilangan nafsu makan,menambah percaya diri,dan menghilangkan rasa sakit dan lelah.

\section{Kanabis}

Nama jalanan: cimeng,ganja,gelek,hasish,marijuana,grass,bhang.berasal dari tanaman kanabis sativa atau kanabis indica.Cara penggunaan: dihisap dengan cari dipadatkan menyerupi rokok atau dengan menggunakan pipa rokok.efek rasa dari kanabis tergolong cepat,pemakai cenderung merasa lebih santai,rasa gembira berlebihan (euphoria), sering berfantasi/menghayal,aktif berkomunikasi,selerah makan tinggi,sensitive,kering pada mulut dan tenggorokan.

\section{Amphetamine}

Nama jalanan: seed,meth,crystal,whiz.bentuknya ada yang berbentuk bubuk warna putih dan keabuan dan juga table.Cara penggunaan: dengan cara dihirup.sedangkan yang berbentuk table diminum dengan air.Ada 2 jenis amphetamine:

a. MDMA(methylene dioxi methamphetamine).Nama jalanan: Inex,xtc. Dikemas dalam bentuk table dan capsul. 
b. Metemphetamine ice,nama jalanan: SHABU,SS, ice.cara penggunaan dibakar dengan menggunakan aluminium foil dan asapnya dihisap atau dibakar dengan menggunakan botol kaca yang dirancang khusus (boong).

\section{Lysergic Acid}

Termasuk dalam golongan halusinogen.Nama jalanan: acid,trips,tabs,kertas.Bentuk: biasa didapatkan dalam bentuk kertas berukuran kotak kecil sebesar seperempat perangko dalam banyak warna dan gambar.Ada juga yang berbentuk pil dan kapsul.Cara penggunaan: meletakkan LSD pada permukaan lidah,dan bereaksi setelah 30-60 medit kemudian,menghilang setelah 8-12 jam.Efek rasa: terjadi halusinasi tempat,warna,dan waktu sehingga timbul opsesi yang sangat indah dan bahkan menyeramkan dan lama-lama menjadikan penggunaannya paranoid.

\section{Sedatif-hipnotik (benzodiazepin)}

Termasuk golongan zat sedative (obat penenang) dan hipnotik (obat tidur).Nama jalanan: Benzodiazepin: BK,Dum,Lexo,MG,Rohyp.Cara pemakaian:dengan diminum, disuntikan,atau dimasukkan lewat anus.Digunakan di bidang medis untuk pengobatan pada pasien yang mengalami kecemasan,kejang,stress,serta sebagai obat tidur.

\section{Solven/Inhalasi}

Adalah uap gas yang digunakan dengan cara dihirup. Contohnya: Aerosol,Lem,Isi korek api gas,Tiner,Cairan untuk dry cleaning,uap bensin.Biasanya digunakan dengan cara coba-coba oleh anak di bawah umur,pada golongan yang kurang mampu.Efek yang di timbulkan: pusing,kepala berputar,halusinasi ringan,mual,muntah gangguan fungsi paru,jantung dan hati. 


\section{Penyalahgunaan Narkotika/Psikotropika di Kalangan Remaja}

1. Narkotika

Sebenarnya narkotika adalah zat ataupun obat yang berasal dari sejenis tanaman atau bukan tanaman, baik berbentuk semi sintetis maupun sintetis. Misalnya : mariyuana yang lebih terkenal dengan nama ganja, bunga koka, kokain, opium yang digolongkan narkotika menurut UU.R.I No 22 tahun 1976, antara lain :

\section{a. Ganja/Mariyuana/Kanabis Sativa ( Halusinogen)}

Ganja yang dikenal juga dengan nama cannabis sativa pada mulanya banyak digunakan sebagai obat relaksan untuk mengatasi intoksikasi (keracunan ringan). Bahan yang digunakan dapat berupa daun, batang dan biji, namun kemudian disalahgunakan pemakaiannya. Banyak orang mengkonsumsi ganja dengan cara menghisap seperti orang menghisap rokok. Ada juga dengan cara memasukkan ke dalam makanan guna mendapatkan rasa nikmat. Membuat ketagihan secara mental dan berfikir menjadi lamban dan pecandunya nampak bodohkarena zat tersebut dapat mempengaruhi konsentrasi dan ingatan serta kemampuan berfikir menjadi menurun.

Mengandung bahan kimia Delta-9tetrahydrocanabinol (THC) yang dapat mempengaruhi pemakai dalam cara melihat dan mendengar.

Bahwa pemakai ganja dalam waktu panjang dapat menyebabkan schizophrenia atau kegilaan.

- Efek yang di timbulkan oleh pecandu ganja ;

- Pemakai cenderung lebih santai

- Rasa gembira yang berlebihan

- Sering berfantasy atau mengkhayal

- Aktif berkomunikasi

- Nafsu makan bertambah besar

- Sensitive

- Kering pada mulut dan tenggorokan

\section{b. Morfin}

Morfin merupakan turuna opium yang dibuat dari hasil pencampuran getah poppy (papaver sormary ferum) dengan bahan kimia lain, sifatnya jadi semi sintetik. Morfin merupakan zat aktif dari opium. Di dalam dunia kedokteran zt ini digunakan untuk mengurangi rasa sakit pada waktu dilakukannya pembedahan/operasi. Ketika pecah perang saudara di amerika serikat tahun 1856 zat ini digunakan untuk serdadu yang luka, 
mengurangi rasa sakit. Akan tetapi efeknya yang negative maka penggunya diganti dengan obat-obatan sintetik lainnya.

\section{c. Heroin}

Heroin ini merupakan turunan morfin yang sudah mengalami proses kimiawi. Pada mulanya heroin ini di gunakan untuk pengobatan ketergantungan morfin, tetapi kemudian terbukti bahwa kecanduan heroin justru lebih hebat. Morfin atau heroin disebut juga putaw. Bentuknya seperti serbuk putih tidak berbau.

- Efek penggunaaan morfin, heroin (putaw) :

- Dapat menekan kegiatan system syaraf

- Memerlambat pernapasan dan detak jantung

- Memperbesar pembuluh darah

- Mengecilnya bola mata

- Adanya perasaan mual-mual dan muntah-muntah bagi korban pemula. Bila overdosis dapat merenggit nyawa

- Mengganggu kerja organ tubuh seperti jantung, lever, paru, ginjal dan usus.

\section{d. Kokain}

Efek dari penggunaan kokain dapat menyebabkan paranoid, halusinasi serta berkurang rasa percaya diri. Pemakaian obat ini akan merusak saraf di otak. Selain memperburuk system pernafasan, penggunaan yang berlebihan sangat membahayakan dan bisa membawakematian. Kokain yang turunannya putaw sangat berbahaya bagi kesehatan manusia.

\section{PSIKOTROPIKA}

Psikotropika adalah obat-obatan yang bukan narkotika, tetapi mempunyai efek yang sama dengan narkotika apabila disalahgunakan. Karena sasaran dari obat-obatan tersebut adalah syaraf-syaraf tertentu dari system syaraf pusat di otak. Pemakaian obat ini menyebabkan perubahan khas pada aktifitas mental dan prilaku.

Contoh obat-obatan yang tergolong jenis psikotropika antara lain :

$\sim$ Shabu-shabu

$\sim$ Ekstasi, dengan nama lain inex, amphetamin (zat psikostimulan)

$\sim$ Rohypnol, pil koplo

$\sim$ Mandrax 


\section{a. shabu}

Zat yang tidak berbau dan bening ini merupakan komoditas baru yang sedang trend dan laris. Dalam dunia kedokteran disebut juga dengan istilah Methamfetamine yang masih saudara kandung ecstasy, karena sama-sama tergolong dalam keluarga psikotropika stimulansia dapat menyebakan ketergantungan

Indikasi :

- $\quad$ Bentuk seperti kristal putih mirip vetsin

- $\quad$ Efek penggunaan zat sama dengan ecstasy menyebabkan kenikmatan semu

- $\quad$ Mengakibatkan efek yang kuat pada system syaraf

- $\quad$ Pemakai akan bergantung secara fisik dan mental

- $\quad$ Penggunaan terus menerus dapat merusak otot jantung

- $\quad$ Zat ini mendorong tubuh melampaui ambang batas kekuatan fisik

- $\quad$ Pemakai mersa terbang dengan perasaan kosong, sementara itu berangsur- angsur membangkitkan kegelisahan yang luar biasa

- $\quad$ Efek langsung penggunaannya menjurus pada prilaku

- $\quad$ Kekerasan

- $\quad$ Berat badan menyusut

- $\quad$ Kejang-kejang

- $\quad$ Dapat menyebabkan impotent

- $\quad$ Over dosis menyebakan kerusakan lever dan paru-paru

Akibat menggunakan shabu :

Berat badan menyusut

Kejang-kejang

Kerusakan ginjal

Gila

Impotent

Halusinasi

Paranoid

Serangan jantung

Mati merana 


\section{b. Ekstacy}

Dari sekian banyak jenis narkoba yang beredar maka ekstasi mungil inilah yang paling banyak di produksi di dalam negeri. Selain dari bahan bakunya mudah di dapat harga jualnya pun bervariasi mulai dari harga golongan "high class eksekutif” selebritis, diatas Rp.100.000 hingga harga banting di warung kafe Rp. 10.000/butir.

Inex nama lain ekstacy ini masih keturunan kandung psikotropika banyak di perjualbelikan bagai kacang goreng. Ekstasi beredar dalam bentuk tablet dan kapsul dengan ukuran sebesar kancing kerah baju yang berdiri dari berbagai macam jenis, diantaranya : Adam, Eva, Flash, Dolar, Bonjovi, Mike Tyson, Playboy, Apple, Angel, White Dove, dan lain-lain.

- Akibat menggunakan ekstasi adalah :

Diare/mual-mual, muntah

Hiperaktif

Gemetar tak terkontrol

Denyut nadi sangat cepat

Hilang selera makan

Rasa haus yang amat sangat

Sakit kepala dan pusing-pusing.

\section{Dampak Penyalahgunaan Narkoba}

Penggunaan narkoba yang tidak sesuai dengan ketentuan disebut penyalahgunaan narkoba. Sungguh memprihatinkan penyalahgunaan narkoba ini yang telah menimpa generasi muda, mulai anak usia SD sampai usia perguran tinggi. Mereka yang terkena penyalahgunaan narkoba akan terjadi disorientasi emosi, kemauan, maupun disorientasi kordinasi psiko motoriknya.

- Tingkatan penyalahgunaan biasanya sebagai berikut:

1. coba-coba

2. senang-senang.

3. menggunakan pada saat atau keadaan tertentu

4. penyalahgunaan

5. ketergantungan 


\section{E. Tanda-Tanda Penyalahgunaan Narkotika dan Zat adiktif}

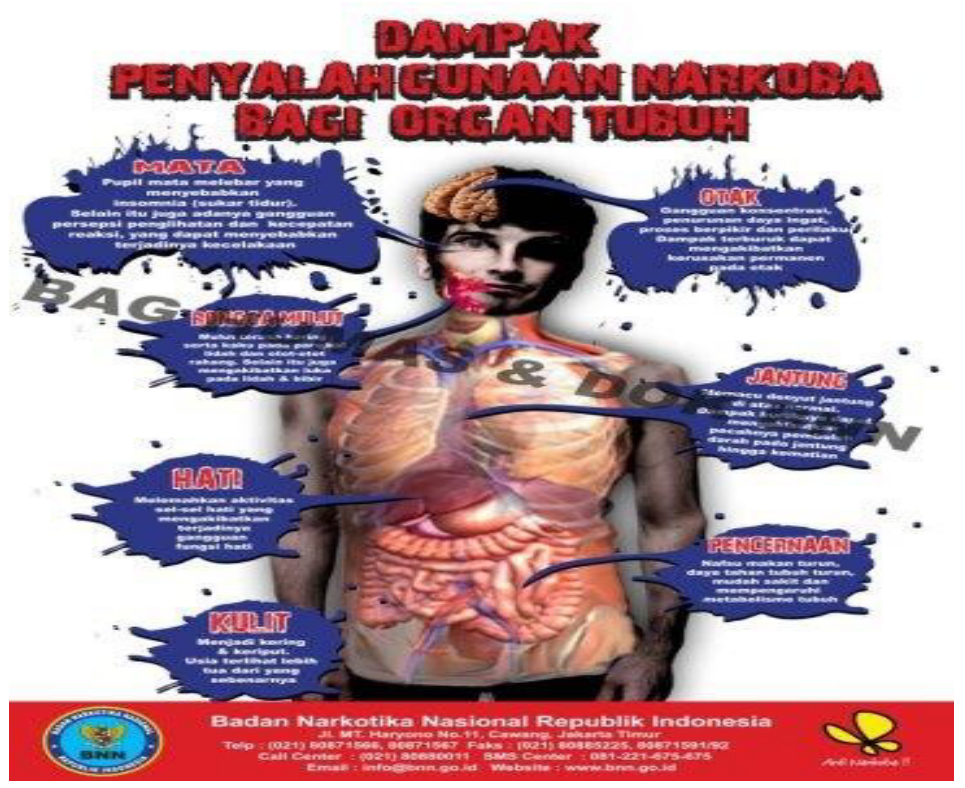

$\cdot$ Fisik

- berat badan turun drastic

- mata terlihat cekung dan merah, muka pucat, dan bibir kehitam-hitaman

- tangan penuh dengan bintik-bintik merah, seperti bekas gigitan nyamuk dan ada tanda bekas luka sayatan. Goresan dan perubahan warna kulit di tempat bekas suntikan

- buang air besar dan kecil kurang lancer

- sembelit atau sakit perut tanpa alasan yang jelas

\section{Emosi}

- sangat sensitif dan cepat bosan

- bila ditegur atau dimarahi, dia malah menunjukkan sikap membangkang

- emosinya naik turun dan tidak ragu untuk memukul orang atau berbicara kasar terhadap anggota keluarga atau orang di sekitarnya

- nafsu makan tidak menentu

\section{Perilaku}

- malas dan sering melupakan tanggung jawab dan tugas-tugas rutinnya

- menunjukkan sikap tidak peduli dan jauh dari keluarga

- $\quad$ sering bertemu dengan orang yang tidak dikenal keluarga, pergi tanpa pamit dan pulang lewat tengah malam 
- suka mencuri uang di rumah, sekolah ataupun tempat pekerjaan dan menggadaikan barang-barang berharga di rumah. Begitupun dengan barang-barang berharga miliknya, banyak yang hilang

- $\quad$ selalu kehabisan uang

- waktunya di rumah kerapkali dihabiskan di kamar tidur, kloset, gudang, ruang yang gelap, kamar mandi, atau tempat-tempat sepi lainnya

- takut akan air. Jika terkena akan terasa sakit - karena itu mereka jadi malas mandi

- $\quad$ sering batuk-batuk dan pilek berkepanjangan, biasanya terjadi pada saat gejala "putus zat"

- sikapnya cenderung jadi manipulatif dan tiba-tiba tampak manis bila ada maunya, seperti saat membutuhkan uang untuk beli obat

- $\quad$ sering berbohong dan ingkar janji dengan berbagai macam alas an

- mengalami jantung berdebar-debar

- $\quad$ sering menguap

- mengeluarkan air mata berlebihan

- mengeluarkan keringat berlebihan

- $\quad$ sering mengalami mimpi buruk

- mengalami nyeri kepala

- mengalami nyeri/ngilu sendi-sendi

\section{F. Faktor Penyebab Penyalahgunaan Narkotika}

Faktor penyebab penyalahgunaan narkoba dapat dibagi menjadi dua faktor, yaitu :

1. Faktor internal yaitu faktor yang berasal dari dalam diri individu seperti kepribadian, kecemasan, dan depresi serta kurangya religiusitas. Kebanyakan penyalahgunaan narkotika dimulai atau terdapat pada masa remaja, sebab remaja yang sedang mengalami perubahan biologik, psikologik maupun sosial yang pesat merupakan individu yang rentan untuk menyalahgunakan obat-obat terlarang ini. Anak atau remaja dengan ciri-ciri tertentu mempunyai risiko lebih besar untuk menjadi penyalahguna narkoba.

2 Faktor eksternal yaitu faktor yang berasal dari luar individu atau lingkungan seperti keberadaan zat, kondisi keluarga, lemahnya hukum serta pengaruh lingkungan. 
Faktor-faktor tersebut diatas memang tidak selau membuat seseorang kelak menjadi penyalahgunaan obat terlarang. Akan tetapi makin banyak faktor-faktor diatas, semakin besar kemungkinan seseorang menjadi penyalahgunaan narkoba. Hal ini harus dipelajari Kasus demi kasus.

Faktor individu, faktor lingkungan keluarga dan teman sebaya/pergaulan tidak selalu sama besar perannya dalam menyebabkan seseorang menyalahgunakan narkoba. Karena faktor pergaulan, bisa saja seorang anak yang berasal dari keluarga yang harmonis dan cukup kominikatif menjadi penyalahgunaan narkoba.

\section{G. Pengobatan Dan Pencegahan}

1. Pencegahan

Penyalahgunaan obat-obatan semakin hari oleh anak-anak menjadi masalah yang semakin memprihatinkan semua orangtua. Dari beberapa penelitian yang sudah dilakukan, disepakati bahwa membangun jalinan komunikasi intens antara orangtua dan anak merupakan alat yang ampuh untuk dapat mencegah hal-hal yang tidak diinginkan. Meskipun demikian, banyak orang tua merasa ragu mendiskusikan tentang penyalah-gunaan obat dan alkohol dengan anak-anak mereka. Sebagian dari kita percaya bahwa anak-anak kita tidak akan terlinbat pada hal-hal terlarang tersebut. Sebagian lainnya menundanya karena tidak mengetahui bagaimana mereka mengatakannya, atau justru takut mereka menjadi memikir tentang hal itu dan mendorong ke arah yang tidak diinginkan.

Dari suatu studi di Amerika menyatakan bahwa banyak kaum muda yang mengikuti program rehabilitasi mengatakan bahwa mereka mengkonsumsi alkohol atau obat-obat terlarang 2 (dua) tahun sebelum orangtua mereka mengetahuinya. Oleh sebab itu, jalinlah komunikasi sedini mungkin dan jangan menunggu sampai anak-anak Anda terlibat masalah tsb.

Jangan takut untuk mengakui bahwa Anda belum mampu menjawab semua pertanyaan yang ada. Biarkanlah anak-anak Anda mengetahui yang menjadi perhatian Anda, dan kemudian Anda dapat bekerja sama untuk memperoleh jawaban yang dimaksud.

- Di bawah ini adalah beberapa tips dasar untuk meningkatkan kemampuan diskusi dengan anak-anak Anda tentang alkohol dan obat-obatan terlarang :

a. Jadilah pendengar yang baik. Yakinkanlah anak Anda merasa ?nyaman? mengungkapkan masalahnya kepada Anda. Dengarkanlah dengan hati-hati dan penuh perhatian semua yang anak Anda katakan. Jangan Anda menjadi marah 
setelah mendengar semuanya. Bila perlu, berikan jeda 5-10 menit untuk menenteramkan hati Anda bila diperlukan. Bila anak Anda tidak menceritakan masalahnya, pancinglah dengan pertanyaan-pertanyaan sekitar sekolah dan aktifitasnya yang lain.

b. Sediakanlah waktu untuk mendiskusikan hal-hal yang sensitif. Penting bagi mereka untuk mengetahui apakah orangtuanya tahu informasi yang benar tentang apayang mereka anggap penting.

c. Berikanlah dorongan. Perbanyaklah dorongan pada hal-hal yang telah dilakukan anak dengan benar, dan jangan terlalu fokus pada hal-hal buruk atau salah yang telah dilakukannya. Hal ini akan mendorong anak-anak untuk belajar merasakan hal-hal yang baik bagi mereka, sehingga mereka dapat mengembangkan rasa percaya diri dalam membuat keputusan yang menyangkut dirinya sendiri.

d. Sampaikan pesan dengan jelas. Saat Anda berbicara tentang penggunaan alkohol atau penyalah gunaan obat-obatan, yakinkan diri Anda memberikan informasi yang jelas dan langsung, sehingga anak mengetahui dengan tepat apa yang diharapkan dari dirinya. Misalnya, Di dalam keluarga kita, dilarang minum minuman yang mengandung alkohol

e. Berilah contoh yang baik. Di samping dari yang bersifat pengajaran, anak-anak belajar juga dari contoh-contoh nyata. Banyak hal tingkah laku anak yang dicontoh dari orangtuanya. Yakinkan diri Anda bahwa Anda sudah bertingkah laku yang benar, seperti yang Anda harapkan dari anak Anda.

f. Komunikasi yang efektif antara orang tua dengan anak tidak selalu mudah berlangsung. Anak-anak dan orang dewasa masing-masing memiliki gaya dan cara yang berbeda dalam menanggapi pembicaraan. Di samping itu, timing dan suasana, juga mempengaruhi suksesnya komunikasi yang akan dilangsungkan. Para orangtua diharapkan secara khusus menyediakan waktunya, tanpa adaketergesaan.

- Di bawah ini ada beberapa tips agar komunikasi yang akan dijalain bisa lebih sukses. Pencegahan yang diantaranya :
a) Memperkuat keimanan
b) Memilih lingkungan pergaulan yang sehat
c) Komunikasi yang baik
d) Hindari pintu masuk narkoba yaitu rokok 


\section{PENGOBATAN NARKOBA}

Pengobatan Narkoba:

- $\quad$ Pengobatan adiksi (detoks)

- Pengobatan infeksi

- $\quad$ Rehabilitasi

- $\quad$ Pelatihan mandiri

Pertolongan pertama penderita dimandikan dengan air hangat, minum banyak, makan makanan bergizi dalam jumlah sedikit dan sering dan dialihkan perhatiannya dari narkoba. Bila tidak berhasil perlu pertolongan dokter. Pengguna harus diyakinkan bahwa gejala-gejala sakaw mencapai puncak dalam 3-5 hari dan setelah 10 hari akan hilang.

- Empat Cara Alternatif Menurunkan Risiko atau "Harm Reduction" :

1) Menggunakan jarum suntik sekali pakai

2) Mensuci hamakan (sterilisasi) jarum suntik

3) Mengganti kebiasaan menyuntik dengan menghirup atau oral dengan tablet

4) Menghentikan sama sekali penggunaan narkoba

5) Detoksifikasi

Detoksifikasi adalah proses menghilangkan racun (zat narkotika atau adiktif lain) dari tubuh dengan cara menghentikan total pemakaian semua zat adiktif yang dipakai atau dengan penurunan dosis obat pengganti.

Detoksifikasi bisa dilakukan dengan berobat jalan atau dirawat di rumah sakit. Biasanya proses detoksifikasi dilakukan terus menerus selama satu sampai tiga minggu, hingga hasil tes urin menjadi negatif dari zat adiktif.

\section{Rehabilitasi}

Setelah menjalani detoksifikasi hingga tuntas (tes urin sudah negatif), tubuh secara fisik memang tidak ?ketagihan? lagi, namun secara psikis ada rasa rindu dan kangen terhadap zat tersebut masih terus membuntuti alam pikiran dan perasaan sang pecandu. Sehingga sangat rentan dan sangat besar kemungkinan kembali mencandu dan terjerumus lagi.

Untuk itu setelah detoksifikasi perlu juga dilakukan proteksi lingkungan dan pergaulan yang bebas dari lingkungan pecandu, misalnya dengan memasukkan mantan pecandu ke pusat rehabilitasi. 


\section{BAB III}

\section{PENUTUP}

\section{A. Kesimpulan}

Narkoba adalah obat obatan terlarang yang jika dikonsumsi mengakibatkan kecanduan dan jika terlalu lama dan sudah ketergantungan narkoba maka lambat laun organ dalam tubuh akan rusak dan jika sudah melebihi takaran maka pengguna itu akan overdosis dan akhirnya kematian.

Narkoba pun ada berbagai jenis seperti: heroin, ganja, putaw, kokain, sabu-sabu,dan alkoholpun termasuk dalam golongan narkoba.

Manfaat yang dirasakan hanyalah sesaat. Tapi mudhorotnya jelas banyak sekali. Banyak organ tubuh menjadi rusak. palagi bila pakai obat bius. Dalah-salah pada saat operasi (karena suatu kejadian) bakal tak mampu lagi bius bagi para penggunanya. Yang pasti biaya untuk bisa mengkonsumsi barang-barang haram itu, sangatlah mahal. Salah-salah bisa masuk bui, kalau ketangkep aparat.

\section{B. Saran}

Berdasarkan pembahasan tersebut, saran penulis adalah sebagai berikut :

1. Jangan pernah mencoba narkoba walaupun itu hanya sedikit

2. Pemerintah harus memberantas peredaran narkoba di Indonesia

3. Orang tua harus lebih memperhatikan anaknya agar tidak terjerumus ke dalam jurang narkoba

4. Perlu peningkatan kerja sama antar masyarakat dengan aparat untuk memeberantas peredaran narkoba

5. Remaja harus diperhatikan oleh semua pihak agar tidak terjerumus pada penyalahgunaan narkoba. 


\section{DAFTAR PUSTAKA}

Tanjung, Ain.2004.Pahami Kejahatan Narkoba. Jakarta: Lembaga Terpadu Pemasyarakatan Anti Narkoba

Wikipedia. 2010. "Narkoba” (online), (http://id.wikipedia.org/wiki/Narkoba. diakses tanggal 12 Nopember 2014, pukul 18:39)

BNK Samarinda. 2007. "Faktor dan Akibat NArkoba" (online)

(http://bnk.samarinda.go.id/index.php?q=faktor-akibat-narkoba. tanggal 12 Nopember 2014, pukul 18:59)

Badan Narkotika Nasional Republik Indonesia

Badan Narkotika Provinsi Jawa Barat

http://www.Sawal99's Blog.htm/Penanggulangan narkoba.htm

http://www.youtube.com

Sinaga, Edi, 2009. Narkoba dan Komitmen Penanggulangan. Newspaper III by Ourblogtemplates.com 